\title{
Practicing Genre-Based Language Teaching Model to Improve Students'Achievement of Writing Skills
}

\author{
Haerazi \\ IKIP Mataram, Indonesia \\ e-mail: haerazi@ikipmataram.ac.id \\ Lalu Ari Irawan \\ IKIP Mataram, Indonesia \\ e-mail:laluariirawan@ikipmataram.ac.id
}

\begin{abstract}
:
This study investigated the use of genre-based language teaching model in the teaching of writing skills to improve students' low achievement. It was aimed at improving the achievement of the fifth semester of English language education study program. This study was classroom action research. The subjects were the $4^{\text {th }}$ semester in academic year 2017/2018. The procedure of the study included two steps namely the preliminary study and the action. The preliminary study collected information dealing with the students' problems and the action presented the steps of the classroom action research. The data were collected through observation, questionnaire, and testing. The data were analyzed quantitatively and qualitatively. The result of the study showed that the genre-based language teaching model can improve the students' writing achievement. Before the action, the average score of students' writing achievement was 55 and the average score after the action was 76. The result was higher than the subject minimum passing grade which is 75. The improvement was supported by two indicators. First, students felt easy to write a descriptive text because the teaching steps guided them to practice writing much more according to the generic structures of the text. Last but not least, students felt compatible with the topics asked to be written because they have background knowledge of those.
\end{abstract}

Keywords: genre-based teaching, teaching of writing, writing skill

\section{Introduction}

Writing is considered as the most complicated language skills to be learned and taught. Writing is a way to transfer ideas for learners. Because of this, learning writing is urgent. Students have gone through various ways to learn it. Learning to write is not like a natural action of learning to speak something. It needs longer time to recognize grammatical systems, patterns, and rules while writing. In addition, students have to put cohesive devices properly. According to Myhill $\&$ Watson (2011), research writing was divided into three main groups: cognitive, linguistic, and 
socio-cultural aspects. In line with the writing skills, when students write things, they must operate the cognitive, linguistic, and cultural aspect in their mind.

Due to the fact that writing is the most complex language skills than the other skills, English teachers or even lecturers in universities are treating their student with various instructional models. The implementation of those is aimed at helping students increase their writing skills. Writing is categorized as one of the productive skills and it is an important skill to be learnt at all level schools and universities. For instance, Jaelani (2017) recommends the content-based instructional model to improve students' writing achievement and creativity. Doing corrective feedback during the classroom is effective to correct grammatical errors made by students and students attain English grammatical knowledge from the feedback process (Sermsook, Liamnimits, \& Pochakorn, 2017).

In order to produce writing texts, students are steered to have higher critical thinking skills (Pei et al., 2017). They conduct learning activities to underpin the relevance, clarity, and logicality of EFL argumentative writing. Furthermore, Anwar \& Arifani (2016) depict that the dominant complexities of English teaching in Indonesia are limited development of learning materials. In the teaching of writing skills, lecturers should be designed their instructional materials based on the students' needs. It is the fact that students' needs are rarely recognized to deliver their exact want to learn English, writing skills in particular.

From junior high schools to senior high schools, students are mandated to write text types that consist of more than one genre, including descriptive texts. The aim of instructional teaching and learning shows that learners are expected to express the meaning of functional texts, monologues, and essays of certain text types (genres). In addition, the enacted text types encompass the procedure, descriptive, recount, narrative, and report texts. These text types are distributed for junior high schools. Meanwhile, at senior high schools, the genres include exposition, explanation, and argumentative texts.

At the university level, teacher students should master and have good capability to write. In fact, teacher students still have difficulties in terms of expressing their thought or ideas with good coherence, cohesion, and mechanics in paragraphs. They also feel uneasy to use vocabularies properly and apply correct tenses while writing. These difficulties are seen in their assignments asked by lecturers. In addition, teacher students show low achievement in writing descriptive texts because they have lack of English knowledge, particularly in writing skills. They feel lack of mastering linguistic features, vocabulary acquisition, and grammatical features.

One of the efforts to cope with the teacher students' difficulties in writing skills is through the implementation of the genre-based language teaching model. There have many types of research been conducted in line with the teaching of writing skills through genre-based instruction. Genre-Based instruction was practiced in writing classes to improve students' writing achievement. It was able to improve students' linguistic aspects, grammatical knowledge, vocabularies, creativities, and generic structure of a text (Cheng, 2006; Nueva, 2008; Tuan, 2011; Abbaszadeh, 2013).

Hyon (1996) states the genre-based language teaching puts a great effect on the relationship between the genres (texts) and contexts. The contexts direct to the purpose of a text, generic structures, and linguistic features of the text. Furthermore, the language teaching model supports learners to organize the structure of a text and offer a deep explanation to them to 
construct an effective written text. Based on these benefits, there is a need to improve teaching and learning writing for English language education students at FPBS IKIP Mataram through implementing the genre-based language teaching model.

\section{Literature Review}

\subsection{The Nature of Writing}

Harmer (2004) represents that "writing is not a language but a form of technology developed as tools by human society". It draws that writing is a way of human to communicate through an inscription of signs and symbols. In addition, writing is seen as a complement of a spoken language. It encompasses systems that rely on structures such speech as vocabulary, grammar, and semantic.

Huy (2015) states writing is "a complex metacognitive activity that offers an individual's knowledge". Teaching writing in EFL context is like an instructional process of studying a language in order to improve vocabularies and punctuation usage (Connors, 2002) and writing often is seen as a process of exploration and discovery (Langan, 2010). As the result, writing defines the written text and the act of constructing a written text. Writers have to express ideas and communicate with the readers through expressing words.

Writing is known as a product skill after the speaking skill. Compared to speaking skill, writing is a more powerful instrument for students to convey their ideas, thoughts, feelings or even judgments about what they have seen and experienced. According to Westwood (2004), writing is a highly complex process involving multiple brain mechanism and linguistic abilities. In accordance with that, writing is a complex activity of the brain to create ideas, words, sentences, paragraphs, and compositions.

\subsection{The Process of Writing}

Writing can be seen as a process and product. As a process, writing seems an activity that involves composition activities. The composition comprises activities of combining structural units of sentences into a larger paragraph or text and cohesive and coherent structure. The composition also can be fragmented into some activities of telling or retelling and activities of transforming. Rusinovci (2015) mentions the writing as a process means how a text is written instead of the final outcome. Meanwhile, writing as a product means students are often asked to create a text type. The created text becomes the product.

In some researches, researchers often refer to writing as a process. It is then transformed into the teaching of writing as an instructional model in teaching writing skills. The stages of writing as process encompass (1) pre-writing, (2) drafting and writing, (3) sharing and responding, (4) revising and editing, and (5) publishing (Qomariyah \& Permana, 2016; Rusinovci, 2015). The common writing process applied in writing class includes drafting, revising, editing, and publishing (Nation, 2009). These steps are categorized as writing activities to compose and combine the structural units of sentences into readable paragraphs.

To improve students' writing skills in a foreign language, it needs special treatment to propose for students. Haerazi et al. (2018) suggest students should be piloted to practice writing various types of genres. It will help students to develop their awareness with the structure of the texts they write. Sartika \& Rachmanita (2017) recommend the use of self-regulated strategy to help students to improve writing achievement in terms of content, grammar, vocabulary, and 
mechanic. EFL writing language learners can develop their writing skills by practicing best teaching steps. Effective writing steps earlier can help students become well-qualified English writers and prepare them to meet the next writing levels (Banu, Benu, \& Wulandari, 2018).

For students, to produce good writing becomes a challenging task because this skill is the most difficult skill of the four language skills. Students often face difficulties in getting ideas, choosing ideas to write, outlining, drafting, revising, and editing their writing. These difficulties could be minimized or even solved by applying the genre-based language teaching model in the writing class. According to Johnson (2013), the aim of the genre instruction is "to help students organize their awareness of the generic structure of the text because it allows them to concentrate on combining the elements effectively both achieving their communicative goals and producing more highly textured writing".

\subsection{The Genre-Based Language Teaching Model}

Genre-based language teaching model has attained popularity among English teachers who teach writing skills in universities of language education study program. This instructional model enables students to ground their knowledge in the texts that students will write in their own target context (Hyland, 2003, Nation, 2009; Tuan; 2011; Nurlaelawati \& Novianti, 2017). The model has views that students are provided with the great learning processes to write.

According to Hyland (2007), the genre teaching model "incorporates a better understanding of how language is organized to achieve social purposes in particular contexts of use". In addition, the model has been applied to the teaching of writing in different countries. In Oklahoma State University in the USA, for an example, Cheng $(2006,2011)$ presented his research that ESP genre approach was able to attain the learning objectives in the teaching of specialist varieties of English to L2 users. The study adds that the genre instructional model facilitates lecturers "to observe how students in classroom learning notice and analyze the generic features of specific texts and they can trace how the features become integrated into their writing".

Nueva (2008) in Philippine shows the genre-based instruction helps students to enhance their proficiency level and their understanding of how a text (e.g. a news article) is structured. The model was able to improve aspects of writing skills such as text organization, use of discourse relational signals, and appropriate use of linguistic aspects.

In Iran, Abbaszadeh (2013) presents the genre instruction to the second language was able "to enhance second language learners' discourse competences and communicative competence through involving students with samples of language in different types of texts". Carstens \& Weideman (2009) indicate that the genre-based instruction through applying its teaching steps was effective to teach academic writing in terms of competences in using source materials and developing structures and academic writing styles.

The genre-based instruction nowadays was employed in the teaching of the four language skills like speaking, listening, and reading skills. It is considered to enable to improve linguistic aspects of writing skills. According to Emilia (2011: 31), genre-based instruction does not only focus on writing skill but also all language skills.

The concept of genre is primarily based on the idea that members of academic communities usually have difficulties in recognizing similarities in the texts that they frequently use for specific purposes. Through genre, they feel easy to read, understand, and write texts because 
they are able to draw on their experience with the texts. Texts are a means of connecting people with each other in ways that carry particular meaning (Hyland, 2003).

Teaching language skills lies in each stage of the genre-based instructional process that supports the developments of all language skills. According to Feez \& Joyce (2002: 28) and Emilia (2011: 33), there are five stages of teaching English using the genre-based instruction, Those are building knowledge of the field, modeling and deconstructing the text, joint construction of the text, independent construction of the text, and linking related text.

\section{Research Methodology}

The research design used in this study is collaborative action research. The researcher worked collaboratively with the real writing lecturers at English educational program. Collaborative action research is as a form of collective self-reflective inquiry in the real situation in order to improve educational practices of an institution or schools. This study applied the three phases which are (1) planning, (2) acting and observing, and (3) reflecting. The planning step presented the plans derived from the results of the discussion between the researcher and the real lecturers to provide some instructional tools and learning steps to overcome the students' problems in writing. The acting step was parts of conducting the arranged plans in the class while observing, the researcher and the real lecturer observed the instructional processes by using the observation sheet. Afterward, the reflecting step aimed at evaluating whether or not the arranged plans achieved the expected improvements.

This study was conducted at FPBS IKIP Mataram which was located in Mataram in the academic year of 2017-2018. It was chosen as the setting of the study because the lecturers of the subjects of Writing I, II, \& III had not applied the genre-based language teaching model in the instruction of writing skills in all levels. Pre-observation was conducted in Writing III in the fourth semester. Based on the researcher and the writing lecturer's agreement, the action was held on Tuesday and Friday in accordance with the subject schedules. Each meeting was piloted in $2 \times 45$ minutes in length. All instructional processes were held in the classroom and the pretest and post-test were conducted in the class, the fourth-semester students in Writing III. Meanwhile, the researcher and the lecturer discussed the processes and results of the test in the classroom and often in the lecturer office.

The procedure of the collaborative action research in this study included two steps. Both were the preliminary study and the action. The preliminary study was aimed at finding out students' problems causing them to have low achievement in writing. Meanwhile, the action was conducted to cope with the problems faced by students in writing. The problems were resolved through planning, acting and observing, and reflecting.

\section{Finding and Discussion}

This section shows descriptions of the research finding and discussion. The presentation is intended to elaborate on the answer to the research question. The case is how the genre-based language teaching model is able to improve students' achievement of writing skills for English language education students at FPBS IKIP Mataram.

The finding of the study presented that the use of the genre-based language teaching model was able to improve students' achievement of writing skills for English language education students. The improvement of students' writing achievement was identified from the result of the writing 
test. The progress of students' writing achievement could be analyzed from the improvement of the students' mean scores from 55 to 76 . The average score of students' writing achievement was 55 before action and it was 76 after the action. It increased by 21 . The passing grade criteria were reached after the action was done in six meetings. Moreover, the average score of the posttest was higher than the minimum passing grade of Writing III which as 75. It was in line with what Taufiqullah et al. (2018) found that genre-based approach facilitated students to practice writing effectively. It also directed students to be autonomous learners.

This study showed that there was improvement of students' writing activities and classroom interaction between students and the teacher in the class. The stages of the genre-based approach led students to conduct writing exercises in various topics. Besides, the various topics presented were familiar for them. It was supported by the students' achievement before the actions. The students' achievement was 55 before and 76 after the action. Detailed information dealing with the distribution of the scores can be seen as follows.

Table : Results of the pretest and posttest of writing achievement

\begin{tabular}{|c|c|c|c|c|c|c|}
\hline \multirow{2}{*}{ Aspects Measured } & \multicolumn{3}{|c|}{ Average Score of Pre-Test } & \multicolumn{3}{|c|}{ Average Score of Posttest } \\
\hline & Rater 1 & Rater 2 & Rater 3 & Rater 1 & Rater 2 & Rater 3 \\
\hline Content & 14 & 14 & 15 & 20 & 20 & 20 \\
\hline Organization & 12 & 12 & 12 & 17 & 17 & 18 \\
\hline Vocabulary & 11 & 12 & 12 & 16 & 16 & 18 \\
\hline Language Use & 13 & 13 & 13 & 17 & 18 & 18 \\
\hline Mechanic & 4 & 4 & 4 & 4 & 4 & 4 \\
\hline Total & 53 & 55 & 56 & 74 & 75 & 78 \\
\hline Average & \multicolumn{3}{|l|}{55} & \multicolumn{3}{|l|}{76} \\
\hline
\end{tabular}

The genre-based language teaching model could improve the students' writing achievement because this model gave students' chances much more to practice writing. In addition, students had opportunities to be more active, interactive, and autonomous in modeling any text given. Table 2 indicated that the students' achievement improved from pretest achievement into posttest achievement of writing skills. The researcher used three raters to assess the students' writing. The average score of students' achievement given by each rater in pretest was 55 . Based on the mean score of students' achievement in the pretest, the level of students' writing skill was at a low level before the genre instructional model had been implemented. Meanwhile, the average score of the three raters in the posttest was 76. This score showed that the students' writing ability was the upper intermediate level.

The assessed aspects were on contents, organizations, vocabularies, language uses, and mechanics. Then, the data showed that each aspect improved. It means that the genre-based language teaching model was able to contribute in the writing classes to increase students' skills to write and create descriptive texts. It was the same finding as Arono and Arsyad (2019) conducted in their research. They stated the genre-based approach was able to lead students write rhetorical quality of article draft. According to Tuan (2011), in Vietnam the application of the genre-based approach had positive effect on students' writing performance and attitudes. Each phase of this approach had different aims to help students practice to write and also to 
perform reading activities. Therefore, the use of genre-based learning model facilitated students to read text strategically such as in the phase of building knowledge of the text.

During the instructional process, the researcher regularly provided discussion in each action in the class, starting from discussing texts and pictures in building knowledge to that of information in the classroom implementation. In this situation, students conducted interaction among the classmates and created collaboration between the teacher and students and among the students. The learning processes were administered through pair works and group works on some occasions. The lecturer provided students with brief explanation through table-by-table to practice much more to write in term of collaboration among the students. As a result, the outcomes of the teaching and learning indicating the social activities were more achieved. It was in line with what Hyland (2003) and Haerazi (2017) found that the genre-based instruction viewed ways of writing as socially situated responses to particular context. In practice, students worked collaboratively in small groups to build their ideas about certain context to write it down in paper.

In the term of interacting with others, students were piloted to understand that the target language they learnt could be made as a resource to make meaning. For instance, in the construction and pair construction processes students provide with some instructional materials that guided them to communicate through English. There was a lot of new information about a number of things that they got from the model texts or input texts and discussion. They knew what they did not know before they joined the learning activities in a stage of instruction. The same thing of that finding is what Emilia (2011) suggested in the writing activities of the joint construction stage. She states the joint construction is a stage in which the teacher starts implementing to practice writing based on the topic provided.

The genre-based language teaching model also directed students to learn about the language itself. Learning about the target language means that they built knowledge of the target language and they internalized how it worked in a text. As an example of the learning process of it in the text modeling and deconstruction, students learnt the language devices, verbs, parts of speech, word orders, gerunds in series that frequently found in a descriptive paragraph. They also studied the tenses such as simple present tenses, a tense that commonly found in a descriptive text. In other words, they learnt about English as the target language and they confirmed some improvements. It helped students create supporting sentences and paragraphs. It is in line with what Lee et al. (2019) found that the mastery of linguistic properties help students to elaborate their ideas in writing.

The writing practice was conducted mostly in individual work in order to treat students to elaborate on their ideas and literacy competence. In doing so, students are assisted by the lecturer through reviewing, revising, and editing processes. They were given some suggestion of how they expressed ideas into a paragraph and how they arranged some words, phrases, and generic structures of an introduction paragraph of descriptive texts. In each learning process, students' writing abilities increased since the research action started although fewer students had the different speed to write. At the same time, the teacher provided with some direct and indirect feedback for students. The two feedbacks gave positive effect for students in writing activities. It was the same finding as Loan (2017). He found the combined feedback was successful in paragraph writing classes at a university in Thailand in terms of teachers and students' comments. In addition, Poorebrahim (2017) in Iran found that explicit feedback was 
essential for revising purposes and implicit feedback was good for learning purposes in writing classes.

\section{Conclusion}

The study demonstrates that the implementation of the genre-based language teaching model was able to improve students' writing skills. The steps of GBLT such as joint construction involve students to discuss the text that they are going to write. In addition, they are able to share meaning, information, and knowledge both the language features and cultural values. In pairs and group works, students got experiences in constructing text types that they learnt in the previous learning step.

The improvements also can be seen from the reflection process qualitatively. Students are able to comprehend the text structures and language features of descriptive texts. In the teaching and learning processes, students become more interested. The classroom atmosphere happens in great interaction and active participation. The GBLT also gives students specific chances to perform the writing product during the discussion and joint construction times.

In the university context, English has been taught as a foreign language and taught and practiced during classroom learning only. Most students rarely have a great opportunity to practice to communicate in English with people, native speakers, or foreigners. The quantity of practicing English in daily life will influence them to practice it in oral or written forms. Therefore, the most compatible teaching and learning arrangement for the classroom context, in particular, must be flexibility by applying many practical instructional models. Even it will be uneasy to practice due to the lecturer is not familiar with the new model of teaching and learning, but at the end, it will make changes for his/her students to learn and practice to write.

In short, writing is a time-consuming practice and experiences for students and even for lecturers. Teaching writing needs to poster students with high motivation and idea to practice their writing in order to enhance their writing skills. Therefore, lecturers should keep on helping students to improve their writing performance further.

\section{References}

Abbaszadeh, Z. (2013). Genre-Based Approach and Second Language Syllabus Design. ProcediaSocial and Behavioral Sciences, 84, 1879-1884. https://doi.org/10.1016/j.sbspro.2013.07.052

Anwar, K., \& Arifani, Y. (2016). Task-Based Language Teaching: Development of CALL, International Education Studies, 9(6), 168-183. https://doi.org/10.5539/ies.v9n6p168

Arono \& Arsyad, S. (2019). The effect of genre-based mentoring on rhetorical quality of research article drafts by Indonesian lecturers in social sciences and humanities, International Journal of Instruction, 12(3), 35-50. https://doi.org/10.29333/iji.2019.

Banu, T. B. J., Benu, S.V.C., \& Wulandari, H. (2018). EFL Writing Students' Objective Needs in Learning to Write: An Overview on the EFL Teaching and Learning Practice, IJELTAL, 3(1), 125-139. Retrieved from www.ijeltal.org

Carstens, A \& Weideman, A. J. (2009). The Effectiveness of Genre-Based Approach Teaching Academic Writing: Subject-Specific Versus Cross-Disciplinary Emphases. Thesis. Univeristy of Proteria. https://pdfs.semanticscholar.org 
Cheng, A. (2006). English for Understanding learners and learning in ESP genre-based writing instruction, Journal of English for Specific Purposes, 25, 76-89.

Cheng, A. (2011). Language features as the pathways to genre: Students' attention to nonprototypical features and its implications. Journal of Second Language Writing, 20(1), 69-82.

Connors, R. J. (2002). Pre-Writing: The stage of discovery in the writing process In C. R. McDonald \& R. L. McDonald (Eds.), Teaching writing (pp. 7). New York: Southern Illinois University Press.

Emilia, E (2011). Pendekatan genre-based dalam pengajaran bahasa Inggris: Petunjuka untuk Guru. Bandung: Rizki Press.

Feez, S. \& Joyce. (2002). Text-based syllabus design. Sydney: NCELTR-Macquarie University

Haerazi. (2017). Genre-based language learning model in teaching writing skills for English department students, International Seminar, 109 (AECON), 108-111.

Haerazi, Irwansyah, D., Juanda, \& Azis, Y. A. (2018). Incorporating Intercultural Competences in Developing English Materials for Writing Classes, International Journal of Language Teaching and Research, 9(3), 540-547.

Harmer, J. (2004). How to teach writing. London: Pearson Education Limited.

Hyland, K. (2003). Genre-based pedagogies: A social response to process, 12, 17-29. https://doi.org/10.1016/S1060-3743(02)00124-8.

Hyland, K. (2007). Genre pedagogy: Language, literacy and L2 writing instruction. Journal of Second Language Writing, 16(3), 148-164. https://doi.org/10.1016/j.jslw.2007.07.005

Hyon, S. (1996). Genre in three traditions: Implications for ESL. TESOL Quarterly, 3(4), 1996, 993-732.

Huy, N. T. (2015). Problems affecting learning writing skill of grade 11 at thong linh high school. Asian Journal of Education Research, 3, 54, 2331-6080

Jaelani, S. R. (2017). Treating of Content-Based Instruction to Teach Writing Viewed from EFL Learners' Creativity, English Language Teaching, 10(11), 156-161.

Johnson, D. C. (2013). Language Policy. England: Palgrave Macmillan.

Langan, J. (2010). Exploring writing: Sentences and paragraphs (2nd ed.). New York: McGraw-Hill.

Lee, B., Fitria, A., \& Ginting, H. (2019). Analyzing literacy and other psychological tendencies using linguistic profile in English expressive writing: Are students able but unwilling to write?, Indonesian Journal of Applied Linguistics, 9(1), 27-37.

Loan, N. T. T. (2017). A case study of combined peer-teacher feedback on paragraph writing at a university in Thailand. Indonesian Journal of Applied Linguistics, 7(2), 15.

Myhill \& Watson. (2011) Teaching writing. In Andre Green (Ed.) Becoming a reflective English teacher. UK: The McGraw-Hill Companies.

Nation, I. S. P. (2009). Teaching ESL/EFL reading and writing. London: Routledge.

Nueva, J. C. (2008). Genre-based Instruction : Its effect on students' news article, (2008), 338350. Retrieved from http://litu.tu.ac.th/FLLT2013

Nurlaelawati, I., \& Novianti, N. (2017). The Practice of Genre-Based Pedagogy in Indonesian Schools: a Case of Preservice Teachers in Bandung, West Java Province. Indonesian Journal of Applied Linguistics, 7(1), 160. https://doi.org/10.17509/ijal.v7i1.6869.

Pei, Z., Zheng, C., Zhang, M., \& Liu, F. (2017). Critical Thinking and Argumentative Writing: Inspecting the Association among EFL Learners in China. English Language Teaching, 10(10), 31. https://doi.org/10.5539/elt.v10n10p31 
Poorebrahim, F. (2017). Indirect written corrective feedback, revision, and learning. Indonesian Journal of Applied Linguistics, 6(2), 184. https://doi.org/10.17509/ijal.v6i2.4843

Rusinovci, X. (2015). Teaching Writing Through Process-Genre Based Approach, US-China Education Review, 5(10), 699-705. https://doi.org/10.17265/2161-623X/2015.10.006

Sartika, D., \& Rachmanita, R. (2017). The Effect of Self-Regulated Strategy Development on Students' Skill to Write Persuasive Text. IJELTAL (Indonesian Journal of English Language Teaching and Applied Linguistics), 2(1), 33-49. https://doi.org/10.21093/ijeltal.v2i1.44

Sermsook, K., Liamnimitr, J., \& Pochakorn, R. (2017). The Impact of Teacher Corrective Feedback on EFL Student Writers' Grammatical Improvement. English Language Teaching, 10(10), 43. https://doi.org/10.5539/elt.v10n10p43

Qomariyah, S., \& Permana, D. (2016). Process Based Approach towards Students' Creativity in Writing English Paragraph. Indonesian Journal of English Language Teaching and Applied Linguistics, 1(11), 37-47.

Taufiqullah, Yuvita, \& Sulistianingsih, E. (2018). Analysis of student attitudes to develop a selfassessment model of genre-based writing class, Journal Lingua Cultura 12(3), 253-258.

Tuan, L. T. (2011). Teaching Writing through Genre-based Approach. Theory and Practice in Language Studies, 1(11), 1471-1478. https://doi.org/10.4304/tpls.1.11.1471-1478

Westwood, P. (2004). Learning and learning difficulties: A handbook for teachers. Victoria: Acer Press. 